\title{
THE CHARGING PARTY BEFORE THE NLRB: \\ A PRIVATE RIGHT IN THE PUBLIC INTEREST
}

The exclusive power to resolve disputes rising under the National Labor Relations Act ${ }^{1}$ (with which the NLRB has been entrusted) has generated confusion over the rights of private participants in the disputesettling process. The statute explicitly grants procedural protections only to the party charged with an unfair labor practice; ${ }^{2}$ it leaves unclear the status of the injured "charging party." While the charging party's interest in participating in unfair labor practice proceedings has been recognized at various stages of the Board's procedure, the Board has sometimes felt constrained by what it considers the public interest in efficient administration to limit the role which the private party is permitted to play. This tension is highlighted by conflicting interpretations by courts of appeal on the issue of whether a charging party has a right to be heard when the Board attempts to settle a complaint directly with the charged party.

Although the Supreme Court has not yet dealt with this problem, it has characterized the right to be free from unfair labor practices as "public" rather than "private," 3 thereby possibly giving rise to the inference that the extent of the charging party's participation in the resolution of a dispute is solely a matter for administrative discretion. Unfortunately, however, the rhetoric of public and private rights has obscured thorough analysis of the relationship between existing dispute settlement procedures and the sometimes conflicting interests of the charging party and the Board. By focusing on the charging party's right to a hearing, this comment examines the NLRB procedural scheme in the light of these conflicting interests. It concludes that not only do compelling policy considerations support a hearing when the charging party objects to a proposed settlement, but also that in light of existing administrative regulations a hearing is required by law.

I

A review of relevant NLRB procedures will provide the context in which this problem can most instructively be considered. Such a pre-

149 Stat. 449 (1935), as amended, 29 U.S.C. \$\$ 151-168 (1958). (Hereafter cited only to U.S.C.)

229 U.S.C. § 160(b)(1958).

3 See, e.g., Amalgamated Utility Workers v. Consolidated Edison Co., 309 U.S. 261 (1940). 
liminary account is useful here not only because it dramatizes the problem by disclosing readily apparent inconsistencies in the charging party's procedural status, but also because it reveals a de facto separation of functions within the NLRB which is of assistance in resolving the troublesome discrepancies posed.

The responsibility for investigating and prosecuting unfair labor practice charges under the NLRA is lodged in the office of the NLRB's General Counsel.4 Any person who alleges that he has been aggrieved by an unfair labor practice may file with the General Counsel the charge necessary to activate the Board machinery. ${ }^{5} \mathrm{~A}$ charge is processed through the General Counsel's regional offices, which are accorded substantial independence in decision-making: they are not under the direct supervision of the Board, and the charging party retains only limited power over the prosecution of his own case. Although a certain degree of responsibility is conferred on the charging party in that he must ensure that there is timely service of his charge on the charged party and prompt submission of evidence, ${ }^{6}$ he may thereafter affect the course of the General Counsel's conduct only by requesting withdrawal of the charge. ${ }^{7}$ Even so, the General Counsel can refuse to permit the charge to be withdrawn. ${ }^{8}$ Entirely within the General Counsel's discretion are whether a formal complaint will issue and

4 See Labor Management Relations Act, 61 Stat. 139 (1947), 29 U.S.C. § I53(d) (1958). One major purpose of this legislation was to divide between the General Counsel and the rest of the Board the functions of investigator, prosecutor and judge. The General Counsel essentially took over operational control of the agency, exercising "general supervision over all attorneys employed by the Board ... and over the officers and employees in the regional offices." Ibid. The function of the General Counsel has been compared to that of a district attorney. See Rosenfarb, THe National Labor Policy \&: How IT Works 615 (1940). Although acting in the name of the Board, his actions were to be independent of Board control. The provision "effectively limits the Board to the performance of quasi-judicial functions." H.R. REP. No. 510, 80th Cong., 1st Sess. 38 (1947). See also Frito Co., W. Div, v. NLRB, 330 F.2d 458, 462 (9th Cir. 1964); International Union of Electrical Workers v. NLRB, 289 F.2d 757, 761 (D.C. Cir. 1960); Haleston Drug Stores, Inc. v. NLRB, 187 F.2d 418, 421 (9th Cir.), cert. denied, 342 U.S. 815 (1951). For a general discussion of the separation provisions and their effect, see Rodgers, Later History and Development of the NLRB, 29 GEo. Wash. L. REv. 252, 256-65 (1960).

524 Fed. Reg. 9102 (1959), 29 C.F.R. \& 102.9 (1965). See, e.g., NLRB v. Swift \& Co., 233 F.2d 226, 231 (8th Cir. 1956); NLRB v. Kobritz, 193 F.2d 8, 15 (1st Cir. 1951); Consumers Power Co. v. NLRB, 113 F.2d 38, 42 (6th Cir. 1940); NLRB v. National Licorice Co., 104 F.2d 655, 658 (2d Cir. 1939), aff'd, 309 U.S. 350 (1940); NLRB v. Hopwood Retinning Co., 98 F.2d 97, 101 (2d Cir. 1938).

624 Fed. Reg. 9095 (1959), 29 C.F.R. \$ 101.40 (1965).

724 Fed. Reg. 9095 (1959), 29 C.F.R. § 101.5 (1965).

8 "Any such charge may be withdrawn, prior to the hearing, only with the consent of the regional director with whom the charge was filed . ." 29 Fed. Reg. 9102 (1959), 29 C.F.R. \& 102.9 (1965). NLRB v. Wemyss, 212 F.2d 465, 468 (9th Cir. 1954); NLRB v. Kobritz, 193 F.2d 8, 15 (1st Cir. 1951). 
what it will contain: ${ }^{9}$ if after a full investigation ${ }^{10}$ the regional director of the General Counsel's office decides that the charge is legally suffi. cient to constitute an unfair labor practice and that evidence is available to support a reasonable conclusion that the alleged violation occurred, he may either attempt to resolve the issue informally or may issue a formal complaint. ${ }^{11}$ Should the regional director refuse to issue the complaint, the only recourse open to the charging party is to appeal to the General Counsel, ${ }^{12}$ whose decision is final and unappealable. ${ }^{13}$

Once the proceeding enters the adjudicative stage, effective control passes out of the hands of the General Counsel into those of the trial examiner and the Board. After the trial examiner's hearing on the formal complaint begins the regional director lacks even the power to withdraw a complaint on his own motion; ${ }^{14}$ to do so, or to amend, settle or dismiss a complaint requires the approval of the adjudicative officers of the Board.15 After the hearing, which is held before a trial examiner in accordance with NLRA provisions ${ }^{16}$ as amplified by agency rules $^{17}$ and the Administrative Procedure Act, ${ }^{18}$ the trial examiner

9 Piasecki Aircraft Gorp. v. NLRB, 280 F.2d 575, 588 (3d Cir. 1960), cert. denied, 364 U.S. 933 (1961).

1024 Fed. Reg. 9095 (1959), 29 C.F.R. $\S 101.4$ (1965). For a general description of the investigative procedure, see Statement of NLRB General Counsel to House Labor Subcommittee on the NLRB, June 29, 1961, CCH LAB. L. REP. 1150.03.

1124 Fed. Reg. 9095 (1959), 29 C.F.R. §§ 101.4, 101.8 (1965).

1224 Fed. Reg. 9095 (1959), 29 C.F.R. $\S \S 101.6,101.7$ (1965).

13 See, e.g., Wellington Mill Div., West Point Mfg. Co. v. NLRB, 330 F.2d 579, 590 (4th Cir. 1964); Division 1267, Amalgamated Ass'n of Street Employees v. Ordman, 320 F.2d 729, 730 (D.C. Cir. 1963); NLRB v. Local 182, Teamsters Union, 314 F.2d 53, 60 (2d Cir. 1963); Retail Store Employees Union, Local 954 v. Rothman, 298 F.2d 330 (D.C. Cir. 1962); Bandlow v. Rothman, 278 F.2d 866 (D.C. Cir.), cert. denied, 364 U.S. 909 (1960). While no court has yet ordered the General Counsel to issue a complaint, the Court of Appeals of the District of Columbia intimated that the district court might properly review the General Counsel's decision on the question of an abuse of discretion in an extreme situation. Retail Stores Employees Union v. Rothman, supra. The existence of such jurisdiction is generally denied, and, at best, has been referred to as dubious. See NLRB 7 . Local 182, Teamsters Union, supra.

14 He may withdraw a complaint at any time before the hearing on his own motion. 24 Fed. Reg. 9102 (1959), 29 C.F.R. § 102.18 (1965).

1524 Fed. Reg. 9102 (1959), 29 C.F.R. \$§ 102.9, 102.17 (1965); General Maintenance Engineers, Inc., 142 N.L.R.B. 295 (1963); Otis L. Broyhill Furniture Co., 94 N.L.R.B. 1452 (1951); United Aircraft Corp., 91 N.L.R.B. 215 (1950).

1629 U.S.C. § 160 (1958).

1724 Fed. Reg. 9095 (1959), 29 C.F.R. § 101.10 (1965).

18 The APA hearing requirements, 60 Stat. 241 (1946), 5 U.S.C. $\S 1006$ (1964), apply to all agencies unless expressly superseded by subsequent legislation respecting a particular agency, 60 Stat. 244 (1946), 5 U.S.C. \& 1011 (1964) or unless expressly excluded from the APA definition of "agency," 60 Stat. 237 (1946), as amended, 5 U.S.C. $\S 1001$ (1964). 
forwards to the Board his findings and a recommended disposition. ${ }^{19}$ The charging party's rights are given formal recognition: he is permitted to file exceptions and a supporting brief with the Board on any matter contained in the trial examiner's decision. ${ }^{20}$ The Board, in response to the charging party's request, may open the record to receive additional evidence ${ }^{21}$ and may also grant permission for limited oral argument.22 Furthermore, the charging party is accorded one final protection: as a "person aggrieved" he may obtain review in a United States Court of Appeals of the Board's final order. ${ }^{23}$

\section{II}

In a recent opinion, the Court of Appeals for the Second Circuit denied the charging party a right to be heard when over his objection the Board and the charged party proposed to enter into a consent order. ${ }^{24}$ This decision conflicts directly with a long-standing Third Circuit rule permitting such a hearing. ${ }^{25}$ Since either the trial examiner,

1928 Fed. Reg. 7973 (1963), 29 C.F.R. § 102.45 (1965).

2028 Fed. Reg. 7973 (1963), as amended, 29 C.F.R. $\$ 102.46$ (1965).

2129 U.S.C. § 160(c) (1958); 28 Fed. Reg. 7974 (1963), 29 C.F.R. § 102.48(b) (1965).

2228 Fed. Reg. 7973 (1963), as amended, 29 C.F.R. \$ 102.46(i) (1965).

2329 U.S.C. $\S 160(\mathrm{f})$ (1958). The charging party has generally been acknowledged to be a "person aggrieved" if the final order is adverse to his interests. See, e.g., American Newspaper Publishers Ass'n v. NLRB, 345 U.S. 100 (1953); Amalgamated Utility Workers v. Consolidated Edison Co., 309 U.S. 261, 266 (1940). The court may review the order immediately or return the record to the Board for the introduction of additional evidence. 29 U.S.C. $\$ \S 160(e)$, (f) (1958).

Even this right to judicial review is limited, however, by the fact that only the Board is authorized to seek enforcement of a favorable court order. Amalgamated Utility Workers v. Consolidated Edison Co., 309 U.S. 261, 269-70 (1940). Denying beneficiaries of an NLRB order the right to petition the courts for enforcement has been criticized in Jaffe, The Public Right Dogma in Labor Board Cases, 59 HARv. L. Rev. 720, 727-28 (1946) and 3 Davis, Administratrve LAw \& 22.13, at 273-75 (1958).

The charging party has also been refused the right to intervene in instances where the Board sought a judicial enforcement order. See Fafnir Bearing Co. v. NLRB, 339 F.2d 801 (2d Cir. 1964); Amalgamated Meat Cutters v. NLRB, 267 F.2d 169 (1st Cir.), cert. denied sub nom., Geilich Tanning Co. v. Amalgamated Meat Cutters, 361 U.S. 863 (1959); Stewart Die Casting Corp. v. NLRB, 132 F.2d 801 (7th Cir. 1942). But see Kearney \& Trecker Corp. v. NLRB, 210 F.2d 852 (7th Cir.), cert. denied sub nom., Kearney-Trecker Employees, UAW v. NLRB, 348 U.S. 824 (1954); West Texas Utilities Co. v. NLRB, 184 F.2d 233 (D.C. Cir. 1950), cert. denied, 341 U.S. 939 (1951) where uncontested interventions were allowed. While the technical arguments evoked by this denial of a hearing before the courts are quite different from those proposed to support the right to a hearing before the Board, many of the same policy considerations apply in both situations.

24 Local 282, Teamsters Union v. NLRB, 339 F.2d 795 (2d Cir. 1964).

25 Marine Engineers' Beneficial Ass'n v. NLRB, 202 F.2d 546 (3d Cir.), cert. denied, 346 U.S. 819 (1953). The case was noted with apparent approval in Piasecki Aircraft Corp. v. NLRB, 280 F.2d 575, 588.89 (3d Cir. 1960) and in International Union of Electrical Workers v. NLRB, 289 F.2d 757, 760 n.5 (D.C. Cir. 1960). Cf. UAW v. NLRB, 23I F.2d 237 (7th Cir. 1956). 
the Board, or the court has the discretionary power to provide the opportunity for a hearing to the charging party, ${ }^{26}$ the issue narrows to whether the opportunity to be heard should be one granted as of right or granted at the discretion of adjudicative officials at some stage in the process. Careful analysis of the decision not only resolves the particular problem but sheds much-needed light on the general confusion surrounding the status of the charging party.

The Third Circuit initially resolved the problem in 1953 by giving full support to the charging party's right to be heard. In Marine Engineers' Beneficial Ass'n v. NLRB ${ }^{27}$ a union filed unfair labor practice charges against a division of the International Longshoreman's Association. After the issuance of a complaint, the Longshoremen and the regional director entered into a stipulation agreement despite the charging party's objection and request for a hearing. The Board subsequently denied the request for a hearing and entered a consent order, ${ }^{28}$ from which the charging party appealed to the court. In concluding that the union was entitled to a hearing, the court took notice of the public nature of the Board's functions but ruled that sections of the Administrative Procedure Act which protect the right to be heard when parties are unable to "determine any controversy by consent" 29 controlled the procedural aspects of the dispute unless expressly superseded by the NLRA. ${ }^{30}$ Reading the APA provisions in conjunction with the NLRA right to petition for judicial review, the court stated:

[T] he charging party, after complaint is issued, does have some standing. The Board may refuse to do anything about his complaint ... But once it does, and once it goes to the extent of filing a complaint, ... he is entitled to have a chance to be heard as the Administrative Procedure Act requires. He has a right to object if after hearing he does not like the result. But he certainly has nothing on which to base

2629 U.S.C. $\$ \S 160$ (e), (f) (1958); 24 Fed. Reg. 9102 (1959), as amended, 29 C.F.R. $\S 102.35$ (1965); 28 Fed. Reg. 7973 (1963), 29 C.F.R. \& 102.45 (1965); 28 Fed. Reg. 7973 (1963), as amended, 29 C.F.R. $\S 102.46$ (1965).

27 202 F.2d 546 (3d Cir.), cert. denied, 346 U.S. 819 (1953).

28 A consent order is issued by the Board pursuant to settlement stipulations which provide for a Board order. 24 Fed. Reg. 9095 (1959), 29 C.F.R. $\$ 101.9$ (1965). "The entry of the order upon stipulation and consent does not detract from its force." Pittsburgh Plate Glass Co. v. NLRB, 313 U.S. 146, 159 (1941).

2960 Stat. 239, 241, 242 (1946), 5 U.S.C. $\$ \S 1004,1006,1007$ (1964). The right to a hearing includes the right to present evidence, submit rebuttal evidence, and conduct cross-examination. 60 Stat. 241 (1946); 5 U.S.G. § 1006(c) (1964).

30 "No subsequent legislation shall be held to supersede or modify the provisions of this chapter except to the extent that such legislation shall do so expressly." 60 Stat. 244 (1946), 5 U.S.C. $\$ 1011$ (1964). 
his objections unless there is a hearing and a record is made so that the court has something to go on. ${ }^{31}$

The court's language indicates that it may have based its recognition of the right to a hearing on two different grounds. ${ }^{32}$ First, the court apparently was saying that the only way to give meaning to the charging party's right under the NLRA to seek judicial review is to create a record for the courts to canvass on appeal. Second, it can convincingly be argued that since the Board has designated charging parties as parties to the proceedings ${ }^{33}$ they are entitled to the full procedural rights, which include the right to be heard, guaranteed by the APA to "any person or agency named or admitted as a party." 34

After eight years without successful judicial challenge, the Marine Engineers rule was diluted by Textile Workers $v . N L R B .^{35}$ Here the charging party objected to a consent order and on review the Court of Appeals for the District of Columbia ordered the Board either to grant the charging party a reasonable opportunity to be heard on its objection to the consent order or to enter upon the record the reasons for accepting the stipulation as the basis for the order despite the union's objections. The court conceded that it was unclear whether the charging party's consent to the stipulation was required, although it did state that subject to restriction in the public interest "the charging party, even though he may not veto a settlement, is given the opportunity for submission of facts and argument, and is recognized as having a substantial part in assisting the Board in fulfilling its public re-

\section{F.2d at 549.}

32 Although the court relied primaxily on the rationale that the charging party had a legal right to be heard, it did attempt to dispose of the efficiency argument and other policy considerations: "This [result], we think, will not seriously interfere with the efficient working of an administrative body. And it will, in our judgment, tend to give the party who feels himself injured and has made a complaint a better chance to have his complaint remedied." Id. at 550 .

33 The Board regulations state that "the term 'party' as used herein shall mean the regional director in whose region the proceeding is pending and any person named or admitted as a party, or properly seeking and entitled as of right to be admitted as a party, in any Board proceeding, including, without limitation, any person filing a charge or petition under the act . . ." 24 Fed. Reg. 9102 (1959), 29 C.F.R. § 102.8 (1965). It should be noted that by retention of this rule despite a recommendation made by an external investigating committee that charging parties not be designated as "parties" the Board indicated that it was administratively desirable to assure the participation of the charging party. See AtTy. Gen. Commitree on Administrative Procedure, National LABOR Relations BOARD 30-32 (1940). While the right to participate as a party is not statutory and is therefore susceptible to extinction in the exercise of the Board's rule making discretion, this past conduct indicates that such change might be undesirable even from the Board's point of view.

3460 Stat. 237 (1946), as amended, 5 U.S.C. $\$ 1001$ (1964).

35294 F.2d 738 (D.C. Cir. 1961). 
sponsibilities." ${ }^{6}$ Unlike Marine Engineers, however, the Textile Workers opinion does not rely on the applicability of the APA. Both a Board regulation and section 1004(b) of the APA afford parties the opportunity for voluntary settlement except where time, the nature of the proceedings, and the public interest require other action. ${ }^{37}$ Textile Workers resolved the question on the basis of the Board regulation alone, failing to recognize that a distinct basis for requiring a hearing on the merits is found in the APA. As Marine Engineers recognized, although the right to be heard at settlement proceedings might properly be curtailed, the additional right given under the APA to be heard on the merits by the adjudicative officer prior to the final disposition is legally required "to the extent that the parties are unable to determine any controversy by consent."

If the Marine Engineers reasoning was weakened by Textile Workers, it was wholly rejected by the Second Circuit in Local 282, Teamsters Union $v . N L R B .^{38}$ In Teamsters, the regional director entered into a stipulation with the charged party, an employer, which provided for rehiring and back pay for certain workers who had been improperly discharged. After the union objected that the stipulation did not provide reinstatement and back pay for other workers who had engaged in a second strike, ${ }^{39}$ the regional director amended the complaint to delete allegations stating that the second strike had been provoked by unfair labor practices and that those workers had also been improperly discharged. ${ }^{40}$ Thereupon the union, complaining that it had been given inadequate opportunity to present its objections to the Board, petitioned the court for review. In order to safeguard itself by complying with the Textile Workers rule that reasons be stated for the denial of a

$36 \mathrm{Id}$. at 740 .

37 Compare "[A]fter the complaint has been issued and a hearing scheduled or even begun, the attorney in charge of the case and the regional director afford all parties every opportunity for the submission. and consideration of facts, argument, offers of settlement, or proposals of adjustment, except where time, the nature of the proceeding, and the public interest do not permit," 24 Fed. Reg. 9095 (1959), 29 C.F.R. $\S$ 101.9(a) (1965), with "The agency shall afford all interested parties opportunity for (1) the submission and consideration of facts, arguments, offers of settlement, or proposals of adjustment where time, the nature of the proceeding, and the public interest permit, and (2) to the extent that the parties are unable so to determine any controversy by consent, hearing, and decision upon notice and in conformity with sections 1006 and 1007 of this title." 60 Stat. 239 (1946), 5 U.S.C. § 1004(b) (1964).

38339 F.2d 795 (2d Cir. 1964).

39339 F.2d at 798.

40 While the amendment might artificially serve to distinguish this case, the opinion properly avoids any such distinction. A decision to amend a complaint and grant full relief on the remaining allegations is in substance the same as granting full relief for only a portion of the original allegations. 
hearing, the Board successfully sought an extension of time in which to file supplemental information setting forth in detail the basis for its approval of the settlement stipulation. ${ }^{41}$ Thereafter the court denied the union's petition for review and held that the Board had the power to enter into settlements over the objection of the charging parties without affording a hearing.

In contrast to Textile Workers, the court met the issue of APA relevance head-on. Instead, however, of finding the APA to be controlling, it attempted to demonstrate that it did not apply on the ground that a charging party is not entitled to the procedural protections granted to a party by the APA. This conclusion is maintainable theoretically because the APA requires that a party be "interested" to qualify for the procedural protections it grants. ${ }^{42}$ But that the distinction drawn by the court between a party who is "adversely affected or aggrieved" 43 and one who is "interested" is questionable at best is evinced by the court's own admission that the distinction is easier to state than to apply. ${ }^{44}$ Furthermore, the court's central proposition that the right to procedural protections afforded "interested parties" by the APA enures only if the party has a substantive private right is impaired by the fact that the court relied on precedent of dubious relevance to buttress its contention: L. Singer \& Sons v. Union Pacific $R . R .{ }^{45}$ the single case cited as authority for this extremely limited concept of "interest," simply held that the particular complainants did not have "some special and peculiar interest which may be directly and materially affected by the alleged unlawful action." 46 Since an un-

41339 F.2d at 799.

4260 Stat. 239 (1946), 5 U.S.C. § 1004(b) (1964).

43 The language is taken from those sections of the APA and the NLRA which create a right to judicial review for persons "adversely affected or aggrieved," 60 Stat. 243, (1946), 5 U.S.C. $\$ 1009(2)$ (1964); or persons "aggrieved," 29 U.S.C. § 160(f).

44339 F.2d at 800.

45311 U.S. 295 (1940).

46311 U.S. at 304 . The issue in the case was whether $\$ 402$ of the Interstate Commerce Act, 52 Stat. 980 (1938), gave a produce merchant located and doing business in one city a right to bring an injunctive action against the construction of a railroad to serve a new market in another city. The statute grants such a right only to a "party in interest." On the basis of this wording, the Supreme Court rejected the argument that the "interest" required was a legislatively-created private right, finding support in language in Western Pacific California R.R. v. Southern Pacific Co., 284 U.S. 44, 51 (1931) to the effect that the requisite interest is present when "some definite legal right possessed by [the] complainant is seriously threatened or that the unauthorized and therefore illegal action of the defendant carrier may directly and adversely affect the complainant's welfare." (Emphasis added.) If any analogy at all can be drawn between Teamsters and the Singer case it might be between the complainants in Singer and a customer of the offending employer or a creditor of the union who might be injured by the results of an unfair labor practice in Teamsters. 
fair labor practice may indubitably affect the charging party in a substantial way, even under the reasoning of the Singer case the charging party should be granted a right to be heard.

As the Teamsters rationale for denying the applicability of the APA can be rejected, it follows that the APA should properly be found controlling. Since the APA specifically grants the right to a hearing by the adjudicative officer subsequent to a settlement proceeding "to the extent that the parties are unable to determine any controversy by consent," 47 the Marine Engineers rule seems to be legally required. But since there exist many inconsistencies in the procedural status of the charging party, and since the cases on the subject are in some disarray, it is desirable to examine broader policy considerations both for and against such hearings. It is in this context that the perception of Marine Engineers that the right to judicial review accorded to parties whose charge has reached the complaint stage would be meaningless were the charging party not permitted to enter its objections on the record assumes independent significance.

\section{- III}

Characterization of the right to protection in the collective bargaining relationship as public in nature has permeated judicial consideration of procedural conflicts arising under the National Labor Relations Act for more than two decades; ${ }^{48}$ the decision in Teamsters that the right to appeal as a "person aggrieved" is an action to vindicate "not a private, but a public right" reflects the continuing effect of that

Furthermore, the case should be distinguished because it dealt not with procedural rights such as those under consideration here but instead with a substantive right. Even on the narrow point of standing to bring an administrative action, the case has been criticized. See 3 Davis, AdMinistrative LAw $\S 22.11$, at 263-65 (1958).

4760 Stat. 239 (1946), 5 U.S.C. § 1004 (1964). Such consent would waive a right to be heard. 24 Fed. Reg. 9095 (1959), 29 C.F.R. \& 101.9(b) (1965). Textile Workers recognized that "provision of section 101.9 (b) for waiver of the right to hearing plainly applies only where the parties have consented to a settlement," and further that "the charging party has not done so in our case." This would negate interpretation of Textile Workers as an implied waiver case. The regulation would also seem to support the view that a right to a hearing remains in effect absent a waiver.

48 An early case which forcefully propounded this concept was Amalgamated Utility Workers v. Consolidated Edison Co., 309 U.S. 261 (1940), where the court quoted from the report of the Committee on Labor of the House of Representatives, H.R. REP. No. 972, 74th Cong., 1st Sess. 21 (1935): "No private right of action is contemplated. Essentially the unfair labor practices listed are matters of public concern, by their nature and consequences, present or potential; the proceeding is in the name of the Board, upon the Board's formal complaint. The form of injunctive and affirmative order is necessary to effectuate the purpose of the bill to remove obstructions to interstate commerce which are by the law declared to be detrimental to the public weal." 309 U.S. at 267-68. See also Haleston Drug Stores, Inc. v. NLRB, 187 F.2d 418, 420 (9th Cir.), cert. denied, 342 U.S. 815 (195I). 
appellation. 49 Yet to rely on the labeling of a right as public or private neglects analysis of the basic interests involved.

Whatever one's framework for analysis and eventual conclusion, the starting point is indisputable: it cannot be gainsaid that the NLRA was intended to serve the public purpose of removing burdens on the economy resulting from industrial strife. ${ }^{50}$ Sound reasons existed at the time the National Labor Relations Act was passed for committing the regulation of collective bargaining to the discretion of a single expert group concerned with broader considerations than the interests of the individual conflicting parties. Labor relations were in a highly volatile state and previous governmental efforts to remedy the situation had proved ineffective.51 To avoid the doctrinal confusion inherent in a system of dispersed authority it was thought important that a single body develop uniform law regarding collective bargaining. ${ }^{52}$ But the Board's budget and facilities were limited. To allocate its resources most effectively, irresponsible charges leading to fruitless litigation had to be eliminated; also, it was obviously desirable to limit concurrent attacks on a single point of unclear law when a single case would resolve the matter. ${ }^{53}$

More than that of any other federal agency, NLRB procedure continues today to make a distinction between "public" and "private rights" significant to persons who have legally-protected interests. The NLRB has exclusive jurisdiction over regulation of collective bargaining: 54 the states are preempted from extending relief, 55 and injured parties may not seek private relief in the federal courts. ${ }^{56}$ This strict limitation on redress available to interested parties is unusual. Although individual citizens have no right actively to seek punishment for a person who commits a crime, nearly all crimes have an analogy

49339 F.2d at 799.

50 See 29 U.S.C. $\$ 151$ (1964).

51 See S. REp. No. 573, 74th Cong., 1st Sess. 1-6 (1935); H.R. REP. No. 972, 74th Cong., Ist Sess. 1-6 (1935).

52 See S. REP., supra note 5I, at 15; Garner v. Teamsters Union, 346 U.S. 485, 490 (1953). See generally Rothman, The National Labor Relations Board and Administrative Law, 29 GEO. WASH. L. REv. 301-04 (1960).

53 See statement by NLRB General Counsel to the House Labor Subcommittee on the NLRB, June 29, 1961, CCH LAB. L. REP. II 1150.

5429 U.S.C. 160(a) (1964); San Diego Bldg. Trades Council v. Garmon, 359 U.S. 236 (1959).

55 See, e.g., Construction and General Laborers' Union v. Curry, 371 U.S. 542 (1963); Meat Cutters v. Fairlawn Meats, Inc., 353 U.S. 20 (1957).

58 E.g., Garner v. Teamsters Union, 346 U.S. 485, 491 (1953). See generally Meltzer, The Supreme Court, Congress, and State Jurisdiction over Labor Relations, (pts. 1-2) 59 ColuM. L. REv. 6,269 (1959). 
in tort.57 The same principle applies to conduct regulated by most administrative agencies. The NLRA may be the exception that proves the rule: the NLRB is one of the very few public agencies entrusted with the sole enforcement of a policy the purpose of which is to guarantee both individual and group interests. ${ }^{58}$

In any attempt to analyze the rights associated with a particular in. terest under the NLRA, Professor Jaffe's recognition that "private and public interests are, both in a substantive and a procedural sense, aspects of the totality of the legal order"59 should be borne in mind. Even if it is granted that a major purpose of the NLRA was to eliminate burdens on the national economy, it may not be inconsistent to recognize other goals embodied in the act. The sanctions available under the NLRA, for example, extend beyond those typical of public enforcement: they are not considered punishment, ${ }^{60}$ nor is relief limited to -injunctions. An important remedial purpose is served by making individual redress available to injured parties. ${ }^{61}$ In this respect the right to judicial review granted parties whose charges have reached the adjudicative stage is a clear-cut recognition within the NLRB procedure of the fact that a charging party does not seek review altruistically to vindicate a nebulous public interest, ${ }^{, 2}$ but instead to assert his own interest through enforcement of his statutorily-protected right to be free from unfair labor practices. ${ }^{63}$ Hence in a case involving

57 See Jaffe, The Public Right Dogma, 59 HaRv. L. REv. 720, 726 (1946).

58 Ibid.

$59 \mathrm{Id}$. at 725 .

60 Cf. Republic Steel Corp. v. NLRB, 311 U.S. 7, 10 (1940): "The Act is essentially remedial. It does not carry a penal program declaring the described unfair labor practices to be crimes. The Act does not prescribe penalties or fines in vindication of public rights or provide indemnity against community losses as distinguished from the protection and compensation of employees."

61 Cf. 29 U.S.C. 160 (c) (1958).

62 Marine Engineers attempted to negate the import of this right to review by describing the right in terms related to a judicially created theory of "private Attorneys General." See Scripps-Howard Radio, Inc. v. FCC, 316 U.S. 4, 14 (1942); FCC v. Sanders Brothers Radio Station, 309 U.S. 470, 476-77 (1940); Associated Indus. v. Ickes, 134 F.2d 694, 704 (2d Cir. 1943). But to speak of a theory only in terms of the language used by courts to justify allowing private persons the ability to seek judicial review of issues in which they have a substantial interest but no substantive legal right, is perhaps to confuse the justification with the real interest being protected. Such a justification is necessary because of the general requirement that an individual interest be shown to exist before a federal court will exercise jurisdiction. Perkins v. Lukens Steel Co., 310 U.S. 113 (1940); Massachusetts v. Mellon, 262 U.S. 447 (1923); Muskrat v. United States, 219 U.S. 346 (1911).

63 See 29 U.S.C. $\$ 157$ (1958). "The affirmative action that is authorized is to make these remedies effective in the redress of the employees' right to assure them selforganization and freedom in representation ...." NLRB v. Fansteel Metallurgical Corp., 306 U.S. 240, 258 (1939). See also Republic Steel Corp. v. NLRB, 311 U.S. 7, 10-11 (1940). Gf. NLRB v. Jones \& Laughlin Steel Corp., 301 U.S. 1, 33 (1937). 
federal preemption under the NLRA, the Supreme Court minimized any realistic difference between the interests being protected in NLRA cases and in cases brought in the courts by private initiative. ${ }^{64}$ If, then, individual remedial interests can be protected under the NLRA without infringing upon the public interest, they should definitely be so served. The fact that victims of unfair labor practices are completely dependent upon the adequacy of Board proceedings for relief argues strongly in favor of affording full procedural protections whenever possible. ${ }^{65}$

It is in light of these policy considerations that one must view the recognition of Marine Engineers that if the charging party's right to review on the record is not to become illusory there must be an opportunity for him to know the reasons for the trial examiner's decision and to record his own evidence and arguments. ${ }^{68}$ In both Textile Workers and Teamsters, for example, the Board's decision was founded on extra-record information, ${ }^{67}$ some of which the charging party never had the opportunity to examine or refute. ${ }^{8 s}$ Aside from possible harm

64 Cf. Garner v. Teamsters Union, 346 U.S. 485, 494-96, 498 (1953): "It often is convenient to describe particular claims as involving public or private rights, and this handy classification is doubtless valid for some purposes. But usually the real signifi. cance and legal consequence of each term will depend upon its context and the nature of the interests it is invoked to distinguish. ... Federal law has largely developed and expanded as public law .... It consists of substituting federal statute law applied by administrative procedures in the public interest in the place of individual suits in courts to enforce common law doctrines of public right .... The conflict [between enforcement by state courts or by the NLRB of the right to bargain collectively] lies in remedies, not rights." $I d$. at 494-96, 498 .

65 See Joint Anti-Fascist Refugee Committee v. McGrath, 341 U.S. 123, 179 (1951).

66 See Pittsburgh Plate Glass Co. v. NLRB, 313 U.S. 146, 176 (194I) (dissenting opinion of Mr. Justice Stone).

67 In both cases, supplemental decisions were issued by the Board to conform to the courts' demands for a demonstration that the denial of a hearing was in the public interest. In the Textile Workers supplemental decision, 135 N.L.R.B. 472 (1962), the Board listed such considerations for approving the order as the policy of encouraging settlements, the risks of ultimate loss after protracted litigation, and the evaluation of "all the factors, legal and factual elicited by the administrative investigation . . . ." 135 N.L.R.B. at 475 . The latter, however, was extra-record information, to which the charging party was not permitted to reply.

In Teamsters, the contents of the reports on which the Board relied were not disclosed to the union. See Brief for Appellant, p. 9, Local 282, Teamsters Union v. NLRB, 339 F.2d 795 (2d Cir. 1964). Significantly, in rewriting its decision for the approval of the court, the Board apparently found that the record was incomplete and attempted to ascertain additional information by telephone. Id. at 8 .

68 Compare "No other major problem of administrative law surpasses in practical importance the problem of use of extra-record information in an adjudication," 2 Davis, ADMrnistrative LAw § 15.01, at 338 (1958), with "If information has come to an agency's attention in the course of investigation of the pending case, it should be adduced only by the ordinary process; it should be considered only if it is in the record ... . The parties, then, are entitled to be apprised of the data upon which the agency is acting. They are entitled not only to refute but, what in this situation is 
to the parties, such a procedure in effect contravenes the statutory scheme by permitting the prosecutor to usurp the Board's fact-finding and adjudicatory functions. ${ }^{69}$

Use of the allocation of functions between the General Counsel and the trial examiner as a reference would provide the most appropriate resolution to the problem of the charging party's right to a hearing. The major objection to permitting hearings as of right has been a fear that it would impair the Board's ability to screen frivolous and repetitious complaints. But that function can be performed without interference by the General Counsel, who is empowered to investigate and dismiss charges at any time before the trial examiner's hearing begins. The General Counsel's reasons for dismissal may relate solely to his concept of the public interest: it is his task to make an unfettered independent determination on that issue in each case. ${ }^{70}$ But once the case proceeds to a hearing he loses absolute control. Hence the concern of the Second Circuit in Teamsters for the retention of the General Counsel's flexibility is misplaced once the complaint reaches the hearing stage. ${ }^{71}$

Even were the General Counsel given discretionary authority to withdraw a case at that stage, by the time a complaint had been issued there would have been ample opportunity for the charge to have been screened and for flexible negotiation with a violator to have occured. Board statistics, in fact, indicate that pre-complaint screening is in practice the NLRB's most effective tool for exercising administrative discretion with maximum flexibility. ${ }^{2}$ Moreover, the conservation of Board resources has not been seriously frustrated by the hearing requirement laid down in Marine Engineers, for it affects an insignificant portion of the total case load. ${ }^{73}$

usually more important, to supplement, explain, and give different perspective to the facts upon which the agency relies." Atr'y Gen. Commitree on Administrative Pro. cedure, Administrative Procedure in Government Agencies, S. Doc. No. 8, 77 th Cong., 1st Sess. 72 (1941).

69 See discussion of the separation of Board functions, note 4 supra.

70 See statement of the General Counsel, supra note 53, for a discussion of the considerations entering the making of decisions by the General Counsel, which decisions may purposely not coincide with those anticipated from the Board.

71339 F.2d at 799 .

72 Of the 13,219 cases submitted in 1962, 11,141 were settled by adjustment, withdrawal or dismissal prior to issuance of a complaint. Approximately 750 additional cases were settled after issuance of a complaint. 27 NLRB ANN. REP. 268 (1962). Only $7 \%$ of the total settlements in fiscal year 1963 were effected over the objections of the charging party. Brief for Appellee, p. 10, Local 282, Teamsters Union v. NLRB, 339 F.2d 795 (2d Cir. 1964).

73 While precise statistics concerning the number of opposed settlements entered into at the adjudicative stage do not exist, an estimate may be attempted by applying the seven per cent opposition rate, supra note 72 , to the number of cases disposed of 
It is clear that the desire for administrative centralization and flexibility is not necessarily incompatible with the protection of procedural rights. In this instance, permitting a hearing as of right after a hearing has commenced does not interfere with the performance of the General Counsel's statutory responsibilities in the most efficient manner possible. The right to be heard does not require a full evidentiary hearing on the merits. ${ }^{74}$ Furthermore, under the statutory scheme the trial examiner and the Board are required to resolve the public interest question again after the first-stage filtering process is complete; the explicit purpose of the division of NLRB functions in the 1947 amendments was to promote independent consideration of the various interests involved.75 If the trial examiner and the Board are to make an informed independent determination of. the public interest, they should have the opportunity to hear those parties whose interests will be affected by the decision. Once the trial examiner's hearing commences, therefore, the charging party's interest in presenting his case deserves recognition. ${ }^{76}$

\section{CoNGLUSION}

If it is conceded that the charging party has a right to a hearing, there remains the problem of how that right is to be enforced. If the Board has entered a final order the statute grants clear-cut authority

during the trial examiner's hearing. In 1962, 263 cases fell into the latter category, indicating a probable additional annual case-load of approximately fifteen to twenty cases. See note 72 supra and authorities cited therein.

74 The issue presented for resolution at the settlement proposal stage is not the ultimate decision on the complaint, but rather whether the public interest calls for the acceptance of the settlement. The charging party may desire to object to only one evidentiary point on which the decision to accept the settlement rests. Further, his objection may go only to the remedy, requiring only an opportunity to place the reasons for his objections on the record. His paramount interest is simply an opportunity to know and refute the arguments and findings upon which the Board might be willing to accept a settlement unsatisfactory to him.

75 See note 4 supra.

76 There will of course be some situations in which "the possibly slight merit of a charge is outweighed by the sure and speedy concessions, the industrial harmony restored, and the savings of Board resources which a settlement can achieve." Local 282, Teamsters Union v. NLRB, 339 F.2d 795, 799 (2d Cir. 1964). However, the true antagonists in the case of an unfair labor practice are the respondent and the charging party. A "sure and speedy concession" which is opposed by the charging party is certainly no assurance of industrial harmony. Teamsters exemplifies in fact something less than expeditious achievement of industrial harmony through the imposition of an unwanted settlement: the union was still on strike over four months after the "settlement" was reached, some eight months after the filing of the charge. Brief of Appellant, supra note 67, p. 5la. While procedural fairness will not guarantee that the losing party will be acquiescent or cooperative, it would tend to minimize suspicion and distrust concerning the decision-making process and would therefore operate to encourage, rather than deter, the acceptance of Board determinations. 
to the appellate courts to review the decision; 77 but if the circumstances are such that the charging party would ordinarily have no right to judicial review, as when the complaint is dismissed or when informal settlement without a "final order" of the Board is obtained, ${ }^{78}$ there may be additional vexing problems. Two recent cases, however, indicate that courts may intervene when direct judicial review is either unavailable or ineffective to redress a wrong. In both cases jurisdiction was premised upon the district court's statutory jurisdiction over civil matters "arising under any act of Congress regulating commerce . . . ."79 In International Union Industrial Workers v. Rothman ${ }^{80}$ a charging party petitioned for injunctive relief to require the Board to hear complaints even though the regional director had entered into an informal settlement over the objection of the charging party. Review under the NLRA was unavailable because the settlement was informal and did not include a final order from the Board. The court reasoned that since Congress felt the need for judicial review from a final order of the Board even after procedural protections had been afforded by a hearing and by intra-agency review, "it is difficult to understand how the Defendants can argue that a decision of the General Counsel, [which is just as "final" to the charging party] as in the instant case, is not reviewable." 81 The court ordered the Board to grant the requested hearing. Similarly, in Deering-Milliken, Inc. v. Johnson ${ }^{82}$ an employer who was a respondent in a pending unfair labor practice proceeding sued for an injunction to prevent a regional director from proceeding with hearings on the charge. The district court held that further hearings, due to the lapse of over five years since the complaint had originally been filed, would be "vexatious, burdensome, harassing," and an abuse of the powers of the Board. ${ }^{83}$ In remanding, the court

7729 U.S.C. $\S 160(f)(1958)$.

78 Cf. Contractors Ass'n v. NLRB, 295 F.2d 526 (3d Cir.), cert. denied, 369 U.S. 813 (1962); Vapor Blast Mfg. Co. v. Madden, 280 F.2d 205 (7th Cir. 1960); Thompson Products, Inc. v. NLRB, 133 F.2d 637 (6th Cir. 1943).

7928 U.S.C. $\$ 1337$ (1958). Cf. Capitol Service Inc. v. NLRB, 347 U.S. 501 (1954) (held to give district courts jurisdiction in civil actions arising under the NLRA).

80209 F. Supp. 295 (D.D.C. 1962).

$81 \mathrm{Id}$. at 297.

82193 F. Supp. 741 (M.D.N.C.), aff'd, 295 F.2d 856 (4th Gir. 1961).

$83193 \mathrm{~F}$. Supp. at 743. The original complaint had been issued on December 4, 1956, and the record necessary for a determination by the Board was completed and closed on November 30, 1958. Instead of issuing an order, however, the Board kept the hearings open at the request of the General Counsel so that proof might be offered as to the relationship existing in 1956-1957 between the plaintiff and certain other textile manufacturing corporations. The case was again submitted to the Board for a decision on the merits on April 5, 1960, but was remanded once again on February 15, 1961, for further hearings. 
of appeals agreed that the right to review after issuance of a final order was ineffective in protecting "the right to have the proceedings brought to a conclusion with reasonable dispatch ..."84 and that the court could therefore properly intervene in the administrative proceeding.

The basic approach of these cases appears valid. Although the NLRA review provision purports to be exclusive, judicial remedies may in some circumstances be necessary to redress infringement by the Board on the rights of private parties for which there is no effective administrative remedy. ${ }^{85}$ Administrative action, short of a final order, may not ordinarily be subject to judicial review, but such action may have significance equal to that of a final order with respect to the interests of a charging party. ${ }^{86}$ The Board will review objections to any such action, but it cannot do so effectively absent the opportunity of the charging party to be heard. Since judicial relief is unavailable to protect the right to be heard when no final order is issued, the district courts should be willing to provide injunctive relief when the right to be heard is denied.

Requiring a hearing to allow a charging party to place on the record his reasons for objecting to a consent order is unlikely to undermine the efficient use of Board resources; if it does prove onerous, the burden can easily be lessened by a change in Board regulations. Meanwhile, by assuring the right to be heard the Board will eliminate the abuses associated with the use of extra-record material and by gaining access to full information improve the likelihood of fair decisions. Further, because aggrieved persons will be afforded more comprehensive procedural protection, greater respect for the Board's administrative process will be promoted, the cooperation of charging parties encouraged and the NLRB thereby enabled more nearly to accomplish its statutory duty to resolve labor disputes in the public interest.

84295 F.2d at 864 .

85 See 295 F.2d at $861-63$.

86 The Court has previously cut through such distinctions to examine agency action in light of its practical effects on the parties. For example, in Rochester Tel. Corp. v. United States, 307 U.S. 125 (1939), the Court eliminated the then prevailing distinction between "affirmative" and "negative" orders as a criterion for determining reviewability of agency action, pointing out that a "negative order" which retains the status quo is as determinative of rights as an "affirmative order" which compels a change. 